\title{
Knowledge regarding HIV/AIDS among Armed Police Force - Banke, Nepal
}

\author{
Roy RK', Roy DK², Ghimire $\mathrm{S}^{3}$, Bist $\mathrm{A}^{3}$
}

${ }^{1}$ Roshan Kumar Roy, Lecturer, Department of Community Medicine, Nepalgunj Medical College; ${ }^{2}$ Deepak Kumar Roy, Lecturer, Department of Conservative Dentistry and Endodontics, Kathmandu Medical College; ${ }^{3}$ Sabal Ghimire; ${ }^{3} \mathrm{Aayush}$ Bist, MBBS II, Nepalgunj Medical College, Kohalpur, Nepal.

\begin{abstract}
Background: A global pandemic threat HIV/AIDS is a matter of concern for developing countries like Nepal. The first case was identified in July 1988 and later became epidemic and then concentrated epidemic among risk group for HIV. Several studies reflected that HIV is associated with many factors among which literacy rate and socio-economic conditions hold the highest rank. Armed Police Force of Nepal are generally with less educational background and very few with higher educational status are at higher level. Thus knowledge regarding HIV/AIDS among this group needs to be assessed.

Objectives: The overall objective of our study was to assess knowledge regarding HIV/AIDS among Armed Police Force in Banke, Nepal.

Methodology: A cross-sectional descriptive study with population size of 295 Armed Police Force was performed which covered the entire population of an Armed Police Force camp in Banke starting from $18^{\text {th }}$ June to $27^{\text {th }}$ July, 2018. A pretested questionnaire containing structural, semi-structural and open ended questions were made as data collection tool. All the soldiers in Armed Police Force camp were interviewed after receiving consent as an ethical clearance.

Results: All 295 armed police forces of our study were aware about HIV/AIDS mainly via mass media (83\%). One hundred and fifty eight respondents still did not know about availability of its treatment. Misconception about its complete cure and vaccination was seen in 23 (7.79\%) and 61 (20.67\%) respondents respectively. Two hundred and one respondents were found knowing about the free health services by government. 287 (97.28\%) respondents knew certain things about prevention. Twenty four respondents admitted of having multiple sex partners and only 19 (79.16\%) among them used preventive measure.

Conclusion: Though all the respondents of our study had known about HIV/AIDS, still they had misconception regarding its treatment and prevention. Many respondents did not even know about the free health services of government. Few of them still do not use any preventive measure.
\end{abstract}

Key words: Armed Police Force; HIV/AIDS; Knowledge; Misconception; Prevention.

DOI: https://doi.org/10.3126/jkmc.v7i4.23323

\section{INTRODUCTION}

TIV (Human Immunodeficiency Virus) is a lenti _ virus (a sub group of retrovirus) that causes HIV infection and over time Acquired Immune Deficiency Syndrome (AIDS). AIDS is a condition in humans in which progressive failure of the immune system allows life-threatening opportunistic infections. The first case of AIDS was reported in United States in June 1981 A.D ${ }^{1}$.According to information given by UNAIDS under the topic "Global statistics" cited on website[https://

Address for correspondence

Mr. Roshan Kumar Roy

Lecturer, Department of Community Medicine

Nepalgunj Medical College, Kohalpur, Banke, Nepal

E-mail: link2roy@gmail.com www.hiv.gov/hiv-basics/overview/data-and-trends/ global-statistics], there were approximately 36.9 million people worldwide living with HIV/AIDS in 2017 and an estimated 1.8 million individuals worldwide became newly infected with HIV in 2017 - about 5,000 new infections per day. With the first case of HIV identification in July 1988, Nepal started its policy response to the epidemic of HIV through its first National Policy on Acquired Immunity Deficiency Syndrome (AIDS) and Sexually Transmitted Diseases (STDs) Control, 1995 (2052 BS) $)^{2}$. A new National HIV Strategic Plan 2016-2021 is recently launched to achieve ambitious global goals of $90-90-90$ which states that by $2020,90 \%$ of all people living with HIV (PLHIV) will know their HIV status by $2020,90 \%$ of all people with diagnosed HIV infection will 
receive sustained antiretroviral therapy, and by 2020, $90 \%$ of all people receiving antiretroviral therapy will have viral suppression ${ }^{2}$. HIV in Nepal is characterized as concentrated epidemic, where majority of infections (more than four in every five new infections) are transmitted through sexual transmission. People who inject drugs, men who have sex with other men and female sex workers are the key populations at higher risk of HIV in Nepal. Male labor migrants (particularly to India, where labor migrants often visit female sex workers) and clients of female sex workers in Nepal are acting as bridging population groups that transfer infections from high risk groups to low risk general population. This research was done among Armed Police Force (APF) Nepal, probing into the depth of literacy level, as HIV transmission in Nepal is associated to level of literacy. The selection of APF in our country is not based on higher education, most of them are generally below School Leaving Certificate (S.L.C level) and very few educated are at higher post only. So as a whole, the force have to perform high physical activities in low income condition and are trained away from their family which ultimately may lead to frustration among the APF. As a result they may be indulged in high sexual activities as a source of pleasure. This study is basically focused on assessing knowledge regarding HIV/AIDS among Armed Police Force (APF) Nepal.

\section{METHODOLOGY}

This study was conducted based on descriptive crosssectional study design and data was collected only once without any follow up. This study was basically focused on assessing the knowledge regarding HIV/ AIDS among APF, Banke, Nepal. Regarding ethical consideration, the ethical consent was taken from APF head and also from each of the respondent who were not willing to participate in the study were not forced. APF respondents were interviewed using questionnaire having structured and semi-structured open ended questions. All the APF residing in a training camp of study site were interviewed giving the study population size of 295. Collected primary data was later tabulated and analyzed using cross tabulation and descriptive calculations. Study started on $18^{\text {th }}$ of June, 2018. Validity and reliability of questionnaire was checked by interviewing $30 \%$ of real study population. Nepali language was used in the questionnaire for better response. All the collected information was assessed using MS-EXCEL and Statistical Package for the Social Science (SPSS) version 22 for descriptive analysis. Analyzed data was thus presented in the form of tables and charts and interpreted accordingly.

\section{RESULTS}

All 295 respondents of our study had heard about HIV/ AIDS. Television or radio was the most common source of information (Table 1). Almost all of them knew that HIV is a sexually transmitted disease (Table 2). While most of them were knowledgeable regarding the sexual mode of transmission, some of them had the impression that HIV could also be transmitted by touching, shaking hands or sharing clothes (Table 3). All of the respondents were aware that its treatment is available at multi-facilitated tertiary and expensive hospitals (Table 4). Most of the respondents were aware that it can be prevented while some of them were not aware of it (Table 5).

\section{Table 1: Source of information regarding HIV/AIDS}

\begin{tabular}{lcc}
\hline Media & Number & Percentage (\%) \\
\hline T.V/Radio & 245 & 83 \\
\hline Family/Friends & 159 & 53.89 \\
Newspaper/Books & 221 & 74.91 \\
Community Field & 179 & 60.67 \\
Programme & 10 & 3.3 \\
\hline Others & & \\
\hline
\end{tabular}

Table 2: Knowledge regarding HIV/AIDS

\begin{tabular}{|lcc|}
\hline Knowledge & Number & Percentage (\%) \\
\hline It is a life threatening disease & 193 & 65.42 \\
\hline Communicable disease & 196 & 66.44 \\
\hline Sexually Transmitted Disease & 272 & 97.62 \\
\hline Bad character disease & 91 & 30.84 \\
\hline Not curable disease & 121 & 41.01 \\
\hline Disease of sex workers & 148 & 50.16 \\
\hline Disease of drug abusers & 64 & 21.69 \\
\hline Brought by foreign workers & 129 & 43.72 \\
\hline Bombay disease & 29 & 9.83 \\
\hline Others & 04 & 1.3 \\
\hline
\end{tabular}

Table 3: Knowledge about mode of transmission

\begin{tabular}{|lcc|}
\hline Source of transmission & Number & Percentage (\%) \\
\hline Touching & 01 & 0.33 \\
\hline Handshaking & 04 & 1.3 \\
\hline Eating together & 06 & 2.03 \\
\hline Unsafe sexual contact & 288 & 97.60 \\
\hline Sharing Syringe & 175 & 59.32 \\
\hline Sharing of clothes \& utensils & 03 & 1.01 \\
\hline Sleeping together & 09 & 3.05 \\
\hline Kissing & 16 & 5.42 \\
\hline Mosquito bite & 71 & 24.06 \\
\hline Vertical transmission & 186 & 63.05 \\
\hline Multiple sexual partners & 207 & 70.16 \\
\hline Others & 01 & 0.33 \\
\hline
\end{tabular}


Table 4: Availability of treatment

\begin{tabular}{|lcc|}
\hline Place & Number & Percentage (\%) \\
\hline District level hospital & 81 & 59.12 \\
\hline Primary health center & 18 & 13.13 \\
\hline Zonal hospital & 107 & 78.10 \\
\hline Medical college hospital & 82 & 13.13 \\
\hline Private hospital & 11 & 8.0 \\
\hline Polyclinics & 05 & 3.64 \\
\hline Community hospital & 18 & 13.13 \\
\hline All health centers & 34 & 24.81 \\
\hline $\begin{array}{l}\text { Multi-facilitated tertiary and } \\
\text { expensive hospitals }\end{array}$ & 137 & 100 \\
\hline
\end{tabular}

Table 5: Preventive measures

\begin{tabular}{lcc}
\hline Preventive Measures & Numbers & Percentage (\%) \\
\hline Safe sexual contact & 287 & 100 \\
\hline Safe blood transfusion & 145 & 50.52 \\
\hline $\begin{array}{l}\text { Using disposable syringes } \\
\text { Isolation of person suffering } \\
\text { from disease }\end{array}$ & 129 & 44.94 \\
\hline $\begin{array}{l}\text { Boycotting the person from } \\
\text { society }\end{array}$ & 07 & 2.43 \\
\hline $\begin{array}{l}\text { Eating separately } \\
\text { Sleeping separately }\end{array}$ & 13 & 1.74 \\
\hline Others & 10 & 4.52 \\
\hline
\end{tabular}

\section{Information about free government health service for HIV/AIDS}

Out of 295 respondents, 201(68.13\%) knew that Government of Nepal provides free services for this disease while remaining 94(31.86\%) were unknown about it. Out of 201 informed respondents, 127(63.18\%) responded that Government of Nepal provides free health services for HIV/AIDS in multi-facilitated tertiary and expensive hospitals.

\section{Information about PMTCT}

Out of 295 respondents, 145(49.16\%) had known about Prevention of Mother to Child Transmission (PMTCT) while 150(50.84\%) had no idea about it.

\section{Knowledge regarding treatment possibility and vaccination}

Out of 295 respondents, 23 (7.79\%) said that HIV/AIDS could be treated while rest $272(92.20 \%)$ were unknown about its treatment. Also 61 (20.67\%) had misconception that vaccine is available for HIV/AIDS while 234 (79.32\%) agreed that vaccination is not available.

\section{Attainment in trainings}

Only $26(8.81 \%)$ respondents had taken training/health education class related to HIV/AIDS via sources such as: School teachers, Health Posts, District Health Office (DHO) etc.

\section{Sexual behaviour}

Out of 295 respondents, $24(8.13 \%)$ admitted that they had sex with multiple partners while rest $271(91.86 \%)$ did not admit so.

\section{Prevention from HIV/AIDS and STDs}

Nineteen (79.16\%) out of 24 respondents practicing multiple sex were adopting preventive measures of STDs while 5 (20.84\%) were not. Condom was found to be the only preventive measure used by all.

\section{DISCUSSION}

All the respondents (295) in our study have heard about HIV/AIDS while a similar kind of research conducted by Wagle CN (NHRC 2009), among 251 policemen of Kathmandu Metropolitan city showed the average of $73 \%$ having knowledge of HIV 3 . There was another research by Rana $G$, which showed that only $66 \%$ of adolescence had knowledge about HIV/ AIDS as communicable disease $\mathrm{e}^{4}$. Trivedi $\mathrm{S}$ conducted a study among secondary level students and found that $88.3 \%$ had heard about HIV/AIDS 5 . Highest numbers of respondents i.e. 245(83\%) have heard about HIV/AIDS via T.V/Radio in our research. Similar type of research conducted by Wagle CN (NHRC 2009) showed Radio/ T.V was the major source for only $59 \%$ individuals ${ }^{3}$.Our study reflected that $288(97.62 \%)$ respondents knew that HIV/AIDS is a sexually transmitted disease among which $97.60 \%$ people had knowledge of transmission via unsafe sex, $52.32 \%$ had idea regarding transmission by contaminated blood and $63.05 \%$ knew about vertical transmission. A research by Bhandari TR showed more than two-third respondents had knowledge on transmission, out of which the highest $(85 \%)$ had responded "unsafe sex", 72\% through "contaminated blood", 67\% via "vertical transmission"and remaining $27 \%$ were unaware ${ }^{6}$. On the other hand, another research done by Bharati $M$ and Bharati $L$ reported that 94.7\% individual knew HIV transmits via needle sharing7. Research by Rana $\mathrm{G}$ on adolescents reflected that $90 \%$ of HIV transmission is due to unprotected sexual contacts ${ }^{4}$. Our research reflected 137 (46.40\%) of the respondents knew that the treatment is possible for HIV/AIDS. A research by Sachdeva $S$ et al., Malik J S, Sachdeva R, Sachdeva TR in Nigeria and Delhi showed proportion of respondents who were aware about existence of 
anti-retroviral drugs for HIV/AIDS were $52.60 \%$ and $28.6 \%$ respectively ${ }^{8}$. In another research by $\mathrm{N}$ Pandey, majority $(37 \%)$ of respondents said that the drug for the treatment of HIV/AIDS is not available, (31.5\%) said there is availability of drug and (31.5\%) did not know about the drug ${ }^{9}$. In this study, 137 responded that the treatment of HIV/AIDS is available but limited to Multifacilitated tertiary and expensive hospital i.e. $68.13 \%$ (201) respondents knew Government of Nepal provides free health services for HIV/AIDS.

Karki KB on an interview under the topic - HIV/AIDS, declining in Nepal taken by Pratik Rimal, which was published in My Republica on $1^{\text {st }}$ December 2017said that "The government is focused on curative measures, but it needs a lot do on preventive measures in order to change behaviors. The government is capable to fund and provide free treatment. We just need proper planning"10. Out of 295 individuals in our study 287(97.28\%) responded that HIV/AIDS can be prevented. Only 19 (79.16\%) of 24 respondents having multiple sex partners were adopting only condom as preventive measure for HIV and STDs. On a research by POLICY Project Nigeria, approximately $12 \%$ of the respondents knew of no ways to prevent HIV/AIDS. Some of the commonly cited modes of prevention of HIV included use of condoms (72.7\%), fidelity (59.7\%), and not receiving injections with shared or re-used needles (38.6\%). Abstinence was mentioned by only slightly more than $10 \%$ of all respondents. Some of the misconceptions or incorrect responses included prevention by not kissing $(10.3 \%)^{11}$. Another research conducted by Awasthi KR et al. reported that unprotected sex is practiced by more than $70 \%$ of the truck drivers among which more than two thirds of the drivers have had experiences of having sex with a sex worker at least once during the course of their travels ${ }^{12}$.

The respondents, $287(100 \%)$ in our study were aware about the fact that HIV/AIDS can be by prevented only by safe sexual contact. However, only five (1.74\%) said that the infected persons should be boycotted from the society. The HIV prevention methods were reported to be condom use, no sexual contact, self-control, avoid sex with sex workers and multiple sex partners as per the research conducted by Karoline Moon Department of Health Policy and Administration ${ }^{13}$. Further another comparative research done by Elna van der Ryst et al. showed that high percentage of respondents i.e. $57.1 \%$ mentioning that people living with AIDS should not have right to normal sex lives ${ }^{14}$. In the present study, 145(49.16\%) respondents had knowledge about Prevention of Mother to Child Transmission (PMTCT). Similar study by Trivedi S showed that only $23.4 \%$ had known about the transmission of HIV5. Out of 295 respondents, $7.79 \%$ said that HIV/AIDS could be treated while $92.20 \%$ were unknown about its treatment protocol. Likewise, 61 (20.67\%) had misconception that vaccine is available for HIV/AIDS while 234 (79.32\%) agreed that vaccination is not available. A research conducted by Jaiswal S and Magar BS et al. reflected that $46.2 \%$ of total respondents knew that vaccine is yet not available for HIV/AIDS ${ }^{15}$. Trivedi $\mathrm{S}$ in her research also reported that $9 \%$ and $11 \%$ of respondents believe that there is cure and vaccine for AIDS respectively ${ }^{5}$. Out of 295 respondents, 24 (8.13\%) admitted that they had sex with multiple partners while rest 271 (91.86\%) did not admit. In a similar research by Oli KB and Maharjan M on their research noted that about $16 \%$ of the participants had expressed their practice of sexual relationship outside more than once, which signifies vulnerability to HIV infection ${ }^{16}$.

\section{CONCLUSION}

Out of 295 respondents in our study, all had heard about HIV/AIDS and T.V/Radio was source of information for $83 \%$ of them. About $97.60 \%$ responded that this disease is transmitted via unsafe sexual contact and only $46.40 \%$ knew that treatment of this disease is possible and is available only in multi-facilitated tertiary and expensive hospitals. Out of 295 individuals, only 68.13\% knew that Government of Nepal provides free health services and among them only $63.18 \%$ responded that free services are available only in multi-facilitated tertiary and expensive hospitals. Regarding prevention, 97.28\% knew that prevention of HIV is possible by safe sexual behavior, also $49.16 \%$ knew about Prevention of Mother to Child Transmission. $79.32 \%$ of the total respondents were aware regarding absence of any vaccinations for HIV. Only $8.81 \%$ had taken any formal trainings/health educational classes regarding HIV. Besides knowledge, only 24 individuals accepted having multiple sex partners. Among them, 19 admitted using preventives measures and condom was found to be the only preventive measure used by all for prevention of HIV, AIDS, and STIs. 


\section{REFERENCES}

1. HIV and AIDS Timeline. [Internet]. [cited on 2017 Jan 10.]. [ Available from: https://npin.cdc.gov/pages/ hiv-and-aids-timeline\#1980]

2. Department of Health Services, Nepal. Annual Report. 2073/74; 23:175-177.[Full text]

3. Wagle CN. A Research Report On Knowledge On HIV \& AIDS And Sexual Behaviors Among The Nepal Police Of Kathmandu Metropolitan, Nepal. NHRC library. December 16 2009.[Full text]

4. Rana G. Knowledge of HIV/AIDSAmong Adolescence At Intellectual Academy In Kumarigal-7, Tushal, Kathmandu, Nepal.JCMC. 2014 Jan; 4(4): 39-41.[DOI]

5. Trivedi S. HIV/AIDS Awareness Level in Secondary Schools of India after Twenty Seven Years.IOSRJHSS.2014 Mar; 19(03):71-75.[Full text]

6. Bhandari TR. Knowledge on HIV/AIDS among Secondary Level School Students in Kathmandu, Nepal. JHAS.2010; 1(01):16-19.[Full text]

7. Bharati $M$, Bharati L .A study on knowledge of HIV/ AIDS among adolescents of higher secondary school in Jajarkot district of Nepal. JCMC. 2014 Jan; 4(3):43-45.[DOI]

8. Sachdeva R, Sachdeva TR, Sachdeva S, Malik JS. HIV/ AIDS knowledge among first year MBBS, Nursing, Pharmacy students of a health university, India. JFCM.2011 Sep-Dec; 18(03):155-158.[PubMed]

9. Pandey N. Knowledge of Pregnant Women Regarding HIV/AIDS. JCMC. 2013; 3(5): 18-21.[DOI]
10. Rimal P. HIV/AIDS Declining In Nepal. My Republica. [Internet]. [citedon 2017 Dec 01.].[Available from: https://myrepublica.nagariknetwork.com/news/ hiv-aids-declining-in-nepal/]

11. Policy Project Nigeria. Knowledge, Attitudes, and Sexual Behaviour among the Nigerian Military Concerning HIV/AIDS and STDs. AFPAC. 2002 Sep; 01:20.[Full text]

12. Awasthi KR, Adefemi K,Tamrakar M. HIV/AIDS: A Persistent Health Issue for Women and Children in Mid and Far Western Nepal.KUMJ.2015 JanMar;;13(49):88-93.[PubMed]

13. Karoline Moon Department of Health Policy and Administration. Knowledge, Perceptions, Attitudes, and Practices of HIV/AIDS: A Comparative Study of Behavior Change in Commercial Sex Workers and Truck Drivers in the Dindigul and Coimbatore Districts of Tamil Nadu, India. UNC-CPID.2002 May; 06:21-23.[DOI]

14. Ryst EVD, Joubert G, Steyn F, Heunis C, Roux JL, Williamson C. HIV/ AIDS - Related Knowledge, Attitudes A N D Practices Among South African Military Recruits.SAMJ.2001 July;91(07):587-91. [PubMed]

15. Jaiswal S, Magar BS, Thakali K, Pradhan A, Gurubacharya DL. HIV/AIDS and STI Related Knowledge, Attitude and Practice among High School Students in Kathmandu Valley.KUMJ. 2005 Jan-Mar; 03(1): 69-75.[PubMed]

16. Oli BK, Maharjan M. HIV/AIDS in Migrant People of Dang District of Nepal. JIST.Jan 2014; 19(2): 71-75. [DOI] 